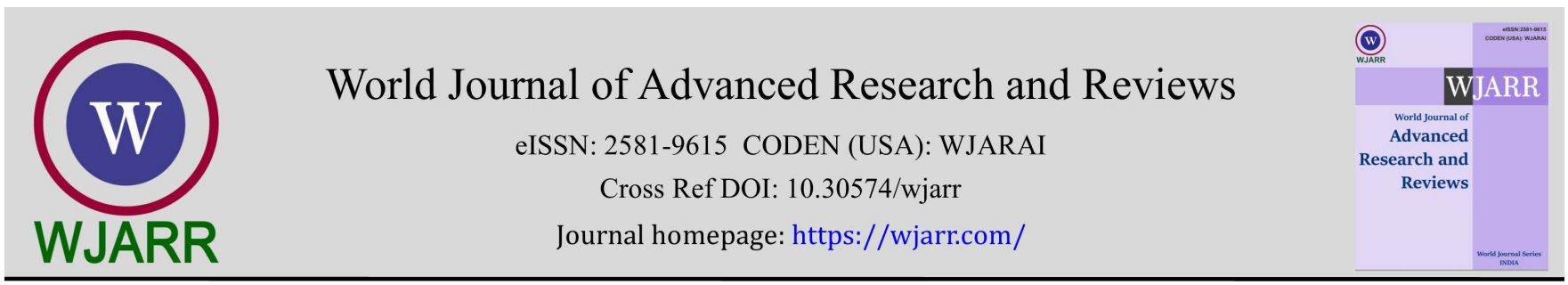

(RESEARCH ARTiClE)

\title{
Condominium Hotel (Condotel) marketing and buying regulations in Indonesia
}

\author{
Zulfina Susanti *, Sri Endah Wahyuningsih and Gunarto \\ Faculty of Law, Sultan Agung Islamic University, Semarang, Indonesia.
}

World Journal of Advanced Research and Reviews, 2022, 13(01), 647-654

Publication history: Received on 12 December 2021; revised on 19 January 2022; accepted on 21 January 2022

Article DOI: https://doi.org/10.30574/wjarr.2022.13.1.0059

\begin{abstract}
The arrangement of the condotel agreement in Law Number 20 of 2011 concerning Flats is not yet clear, as shown by the absence of a dictum governing hotel condos. Hotels, while Condominiums or flats are only related to the ownership of flats that are more in the context of private settlements, the absence of a clear Condotel arrangement makes Condotel owners often lose money. The purpose of this study is to analyze the current Condominium Hotel (CONDOTEL) arrangement in Indonesia and analyze the weaknesses of the current Condominium Hotel (CONDOTEL) arrangement in Indonesia; the research paradigm in this dissertation is constructivism with non-doctrinal research methods with a sociological juridical approach. The results of existing research state that the implementation of hotel condominium agreements so far does not have a juridical footing in Indonesia, this has resulted in many developers and builders who often seek big profits without heeding the principles of good ethics in buying and selling agreements and managing hotel condominiums. The weakness in the hotel condominium agreement policy is the weakness of the legislation in the form of not regulating the contents of the hotel condominium agreement and the position of the hotel condominium in Law Number 20 of 2011, the weakness of law enforcement in the form of no supervision related to the sale and purchase agreement and hotel condominium management., and the habitual factor of hotel condominium development and construction actors who seek profit through sale and purchase agreements and hotel condominium management by excluding consumers or hotel condominium owners.
\end{abstract}

Keywords: Condominium Hotel; Value of Justice; Arrangement; Agreement

\section{Introduction}

Settlement is a very important thing in urban life today. This is because urban spatial planning is increasingly limited due to economic development activities that continue to progress rapidly, often neglecting decent residential areas. This makes every business actor begin to touch on the settlement business [1].

Condominium is one alternative in answering this problem. Healthy and comfortable housing within the scope of a condominium becomes an attractive thing for every community who needs a healthy and comfortable residence in the midst of dense urban life, including condominium hotels. The density of the hospitality business often demands renewal of ideas to increase customer satisfaction, since the hotel has been an important means of supporting community mobility in carrying out economic activities in various regions. Hotel condominiums are expected to be able to improve excellent service in terms of providing public accommodation to support the increasingly high turnover of community mobility in the current era of industrialization 4.0. The increasing public interest in condominium hotels can be seen in the development of condominium hotels in Indonesia. It can be seen that sales of condominium hotels in 2020 are around $95.4 \%$ [2].

\footnotetext{
${ }^{*}$ Corresponding author: Zulfina Susanti

Faculty of Law, Sultan Agung Islamic University, Semarang, Indonesia.

Copyright $(2022$ Author(s) retain the copyright of this article. This article is published under the terms of the Creative Commons Attribution Liscense 4.0.
} 
In its development, the business world in the midst of uncertain conditions certainly faces various kinds of problems, not least at this time, the era of the covid-19 pandemic has caused a lot of domino effects in the business world, this can be seen by the number of entrepreneurs who have to close due to increasing expenses and not matched by a large income either. So that the world of capital is increasingly important in order to maintain a business at this time. This often causes condotel developers and builders to act pragmatically, one of which is seeking profit through condotel management agreements that are detrimental to condotel owners. This clearly contradicts the concept of law and justice in Indonesia [3].

In the Preamble to the 1945 Constitution of the Republic of Indonesia (hereinafter abbreviated as the 1945 Constitution of the Republic of Indonesia), the fourth paragraph states that the establishment of the Indonesian State Government is aimed at promoting general welfare. The opening mandate of the 1945 Constitution of the Republic of Indonesia was followed by Article $28 \mathrm{H}$ paragraph (1) of the 1945 Constitution of the Republic of Indonesia and Article 31 of Law Number 39 of 1999 concerning Human Rights [4].

The constitutional mandate means that every citizen has the right to have a place to live either individually or together, so that the State is obliged to regulate fairly and clearly regarding guarantees for the fulfillment of the right to have a healthy settlement. This is realized through Law Number 1 of 2011 concerning Housing and Settlement Areas, vide Article 46, the Government issued Law Number 20 of 2011 concerning Flats (hereinafter abbreviated as Law on Flats). Article 1 number 1 of Law Number 20 of 2011 concerning Flats states that: Flats are high-rise buildings built in an environment divided into functionally structured parts, both horizontally and vertically and are units that each can be owned and used separately, especially for dwellings equipped with shared parts, shared objects, and shared land [5].

Then Article 1 point 2 of Law Number 20 of 2011 concerning Flats states that: Implementation of flats is an activity of planning, development, control and utilization, management, maintenance and care, control, institutional, funding and financing systems, as well as the role of the community involved implemented in a systematic, integrated, sustainable, and responsible manner. Furthermore, Article 1 point 7 of Law Number 20 of 2011 concerning Flats states that "public flats are flats that are organized to meet the housing needs of low-income people". Then Article 1 point 8 of Law Number 20 of 2011 concerning Flats states that "special flats are flats organized to meet special needs". Furthermore, Article 1 point 9 of Law Number 20 of 2011 concerning Flats states that "state flats are flats owned by the state and function as a place to live or stay, a means of fostering families, as well as supporting the implementation of the duties of officials and/or civil servants. ". Article 1 number 10 of Law Number 20 of 2011 concerning Flats states that "commercial flats are flats that are organized for profit". Furthermore, Article 1 number 18 of Law Number 20 of 2011 concerning Flats states that "the owner is anyone who owns a condominium unit". Article 1 number 20 of Law Number 20 of 2011 concerning Flats states that "the manager is a legal entity in charge of managing flats". Article 1 number 21 of Law Number 20 of 2011 concerning Flats states that "the association of condominium owners and residents, hereinafter referred to as PPPSRS, is a legal entity consisting of condominium owners or residents" [2].

With regard to the above provisions, the management of commercial flats includes operational activities, maintenance and care of shared parts, shared objects, and shared land carried out by legal entities registered and obtaining business permits from the Regent/Mayor. Commercial Flats are factually in the form of hotel condominiums (hereinafter abbreviated as Condotel), which is managed by a Limited Liability Company by entering into a management agreement with the Association of Owners and Tenants of Flats, hereinafter referred to as PPPSRS, which is a legal entity consisting of the owners or occupants of condominium units, however, the Flats Law does not further regulate the condotel management agreement. As a result of the unregulated agreement regarding Condotel, often the Condotel agreement only prioritizes the interests and profits of the developer, not the party who is the Owner and Occupant of the Condotel Unit or the owner of the Condotel [6].

\section{Material and methods}

\subsection{Research Objectives}

- To analyze the current marketing and buying and selling arrangements for Condominium Hotels (CONDOTEL) in Indonesia.

- To analyze the current weaknesses of the Condominium Hotel (CONDOTEL) marketing and buying and selling arrangements in Indonesia. 


\subsection{Research Method}

The type of legal research used is non-doctrinal. In this non-doctrinal legal research, law is conceptualized as a manifestation of the symbolic meanings of social actors as seen in the interactions between them. That the real reality of life does not exist in the empirical realm which is also the observable realm, does not appear in the form of objectively (especially normative) patterned and structured behavior and therefore can be measured to produce quantitative data. The reality of life actually only exists in the realm of meaning that appears in the form of symbols that can only be understood after being interpreted. Such a reality cannot be easily "captured" through external observation and measurement. These realities can only be "captured" through experience and internal appreciation that produces a complete picture of understanding.

\section{Results and discussion}

\subsection{Condominium Hotel (Condotel) Marketing and Buying Arrangements in Indonesia}

In Indonesia, the form of a condotel is a building consisting of units like apartments. In general, the condotel is then sold to investors with various offers, but then the management of this condotel unit will later be managed by the hotel operator whose job is to market and rent out the condotel to guests or tourists who will stay at the condotel. The legal basis for condotel itself is rooted in various laws and regulations governing flats which are basically based on the right of everyone to live in prosperity, physically and mentally, to live, and to obtain a good and healthy living environment as regulated in Article $28 \mathrm{H}$. paragraph (1) of the 1945 Constitution of the Republic of Indonesia (UUD NRI 1945) [2].

The right to live, which was later embodied in Law number 20 of 2011 concerning Flats (UU Flats) which regulates various principles in the administration of flats which include the principles of welfare, justice and equity, harmony and balance. The existence of this principle is the basis for the implementation of flats, including in this case the legal relationship between the manager and the owner of the condotel in the process of buying and selling condotel. However, specifically and clearly there is no legal regulation that regulates hotel condominiums. Ownership of this apartment unit is then known as the concept of Strata Title ownership which is intended as ownership of a portion of the space in a multi-storey building such as an apartment or flat or in other words the Ownership of the Flat Unit. Thus, this concept allows a person as a right holder to be entitled to a part of the common part, common object or shared land which does not refer to a particular part or location but in the form of a proportion or percentage of ownership whose ownership is proven in the form of a certificate of Ownership of the Flat Unit which allows rights holders use it for other purposes [7].

From the legal substance, initially the legal relationship occurred between individuals as prospective condominium owners and development actors. This legal relationship occurs until the buying and selling stage occurs, meaning that there is a transfer of ownership rights previously held by the developer to the owner of the condominium. In essence, PPJB only regulates prices and payment procedures, guarantees for development actors, rights and obligations of the parties, time for building handover, building maintenance, building use, transfer of rights, cancellation and expiration of PPJB, dispute resolution [8].

Maintenance of buildings in this case is during the construction period, not sustainable management. Regarding the management process of the condominium, the Flats Law further stipulates the formation of the Association of Flat Owners and Tenants (PPPSRS), which is an association with a legal entity consisting of owners and residents of the condotel [9].

The condominium management agreement will occur between the Association of Flat Owners and Tenants (PPPSRS). Where the manager formed or appointed by the PPPSR must meet requirements such as the status of a legal entity and have a business license from the regent/mayor, for the Province of the Special Capital Region of Jakarta, the permit is given by the governor. The manager formed by the Association of Flat Owners and Occupants will later become a separate management organization from the management organization of the Association of Flat Owners and Tenants (PPPSRS) and is the result of a transparent selection from several managers. Further arrangements regarding this management by law are left to the regional government to make arrangements in the form of regional regulations (Perda) and governor's regulations (Pergub) [10].

This can be seen, one of which is in Pergub DKI Jakarta number 132 YEAR 2018 concerning Guidance on the Management of Owned Flats (Pergub DKI 132/2018) as a material for discussion. In Pergub DKI 132/2018, provisions are regulated in operational activities for the management of Flats which at least include socializing the use of condotel, shared parts, shared objects, shared land, and occupancy, operation of technical equipment and building equipment 
inside and outside the Flats, as well as the management of environmental order and cleanliness. In addition, regarding the activities of maintenance and care and management [11].

As mandated by the regulation above, the management of the condotel here must be carried out by a manager who is a legal entity who is obliged to register and obtain a business license and operational permit and the Governor. This legal entity must be a legal entity that can perform work and has competence in accordance with the provisions of the legislation. Managers in carrying out their obligations may cooperate with individuals or other legal entities which must be stated in a written cooperation agreement and obtain written approval from the Management [12].

Both the manager formed by the Association of Flat Owners and Occupants (PPPSRS) and appointed by PPPSRS have several criteria that must be met. For example, if the manager is formed by the Association of Flat Owners and Occupants, then the manager is a separate legal entity from the PPPSRS organization and has competent management and human resources, has the ability to manage Flats, and has a business license in accordance with the provisions of the legislation invitation. And if the manager is appointed by PPPSRS, then the appointment of the manager is carried out by an open and transparent auction process and is followed by the business entity providing services for the management of the Flats [13].

The manager appointed by PPPSRS must at least have a business license and an operational permit for the management of Flats in accordance with the provisions of the legislation, have sufficient business capital to carry out the management, have sufficient experts and human resources and have a certificate of professional competence according to the field. expertise issued by the authorized agency, has experience in the management of high-rise buildings, and has credibility and a good level of public trust. Furthermore, Pergub DKI 132/2018 stipulates that managers who are formed or appointed carry out tasks based on a cooperation agreement for a certain period, with the PPPSRS management signed by the management on behalf of PPPSRS for a period of at least 1 year or a maximum of 2 years. In carrying out their duties, the manager is responsible to PPPSRS in the implementation of the management and utilization of Joint Parts, Joint Objects and Joint Land. Of course, in this case, Pergub DKI 132/2018 stipulates that the management cooperation agreement must not harm the mutual interests of the Owner and/or Tenant [14].

So that this management agreement does not harm the common interests of the owners and/or penguins, which are then handed over by the governor to both parties as part of the principle of freedom of contract. Basically, the manager is given the mandate to carry out the task of carrying out the management of the Flats and their environment in the shared section, shared object and shared land, carrying out the operation, maintenance and care of the shared section, shared object, and shared land, supervising order and security as well as the use of and utilization of common parts, mutual objects, and mutual land in accordance with their designation, carry out other tasks assigned by the PPPSRS management in accordance with the agreement, and prepare standard operating procedures, maintenance and care of Flats for approval by the PPPSRS Management.

The Manager also has the obligation to carry out management as well as possible in accordance with the Management Cooperation Agreement, assist the PPPSRS management to submit a management fee bill to each Owner and/or Tenant to be deposited into the PPPSRS account, carry out other tasks assigned or authorized by the PPPSRS Management as stated in the management agreement, submit the management performance report, annual financial report, and accountability report to PPPSRS, and announce the Annual Financial Report widely [14].

By carrying out these duties and obligations, the manager in carrying out the management is entitled to receive a number of management fees paid by PPPSRS to the manager in accordance with the cooperation agreement for the management of the Flats. So to ensure this is carried out properly, Pergub 132/2018 regulates the role of the Regional Government to provide technical guidance and control over the management of Flats. The technical guidance and control as referred to is carried out by the Service together with the Mayor which includes the implementation of socialization of laws and regulations, providing guidelines and standards for the implementation of PPPSRS, and providing guidance, supervision and consultation to the PPPSRS management [15].

The regional government in this case has the authority to exercise control through giving warnings and warnings, giving administrative sanctions, and revocation of registration letters and ratification of management by the Office. The warning referred to in this case can be given if the PPPSRS management and/or PPPSRS supervisor violates or takes actions that are contrary to the provisions of the legislation and if the managing legal entity violates or takes actions that are contrary to the provisions of the laws and regulations. In the event that development actors, PPPSRS management and PPPSRS supervisors as well as managing legal entities do not heed the warning, the regional government will issue the first and second warning letters within a certain period of time. If it is still not heeded, then the service in this case can give administrative sanctions in the form of revocation of recording and ratification of the 
management of PPPSRS, or provide recommendations to the agency responsible for licensing matters to revoke business licenses from development actors and/or business permits/operating permits of the agency management law [16].

The regulation in Pergub DKI 132/2018 has actually placed an equal position between the manager and PPPSRS both regulating the rights and obligations for both, as well as the threat of strict sanctions that are not only imposed on the manager but also on PPPSRS. It's just that the laws and regulations in essence do not regulate the standard format of the agreement or guidelines regarding what cargo materials are at least listed in the hotel condominium management contract.

\subsection{Weaknesses of Marketing and Buying Condominium Hotel Arrangements in Indonesia}

The laws and regulations do not regulate how the standard format of the agreement or guidelines regarding the content of what content is at least included in the hotel condominium management contract, even in the relevant legal regulations it has not been clearly defined regarding the definition and criteria for hotel condominiums.

This has resulted in many problems in the agreement for the construction and management of hotel condominiums today. The absence of regulation regarding hotel condominium agreements in the Housing Law, Flats Law and PUPR Ministerial Regulation 11/2019 resulted in the management agreement between PPPSRS and condotel managers being only guided by the article regarding the Civil Code agreement,

When referring to the Civil Code, then at least there are consensual agreements, real agreements, and formal agreements whose distinction is intended to determine the legal requirements of each of these agreements. For example, the condition for the validity of a consensual agreement is an agreement between the parties who made it as stipulated in Article 1320 of the Civil Code [17].

The condition for the validity of a real agreement is that certain actions have been carried out, for example in an agreement for safekeeping of goods as stipulated in Article 1697 of the Civil Code. The condition for the validity of a formal agreement is that certain formalities have been fulfilled, for example on a grant as stipulated in Article 1682 of the Civil Code. Then the Civil Code in articles 1313 and 1314 of the Civil Code also triggers two types of agreements, namely a unilateral agreement, namely an agreement in which one party gives an advantage to the other party, without receiving a benefit for himself and a reciprocal agreement, namely an agreement that creates basic obligations for both parties. For an agreement that is reciprocal, as a juridical consequence the two parties who make the agreement are as determined by Article 1338 of the Civil Code. All agreements made legally apply as law to those who make them [18].

The agreements cannot be withdrawn other than by agreement of both parties, or for reasons which are stated to be sufficient by law. Agreements must be executed in good faith. So that a reciprocal agreement contains two legal principles, namely the principle of binding power of the agreement (pacta sunt servanda), and the principle of freedom of contract, in addition to the precedence principle called the principle of consensualism (Article 1320 of the Civil Code). In civil law countries, it is customary to apply the principle of pacta sunt servanda and the principle of freedom of contract in making an agreement. This is evidenced by the open system adopted by the Third Book of the Civil Code as a consequence of Indonesia as a country that implements civil law. This open system means that the law of agreement gives the parties the widest freedom to enter into any agreement, as long as the contents do not violate the law, public order and morality (causa which is not prohibited) [19].

Basically the formation and application of law will not be separated from the legal principles that apply in a legal system considering the position of the legal principle itself as conveyed by Paul Scholten is defined as the tendencies required by law by the notion of decency. That is, the legal principle is the basic thought contained in the legal system which then certainly influences and applies in the formation of the agreement as a legal act, including in this case it should underlie the cooperation agreement between the management and PPPSRS [20].

Unfortunately, because there is no legal substance that regulates how this cooperation agreement should be made, the form of the management cooperation agreement and PPPSRS in its implementation when referring to Salim HS' terminology regarding nominee contracts and innominate contracts, it can be categorized as an innominate contract, namely a contract that arises, grows, and develops in practice because of the freedom of contract as stated in Article 1338 paragraph (1) of the Civil Code. In fact, these various innominate contracts are generally standard contracts that contain unequal rights and obligations of the parties. This is because the formal standard contract with the principle of "take it or leave it" offered to consumers in the field of goods and services does not provide an opportunity for consumers to negotiate, where consumers are forced to agree to the form of the contract. 
The characteristic of this contract is that the weak party does not have a bargaining position. The point is, if the contract is generally made through a negotiation process between the two parties who want to agree and has the content material in the form of the agreed negotiation results, then in this innominate contract, in general, all clauses are agreed upon. - the clause has been standardized by the user and the other party basically does not have the opportunity to negotiate or ask for changes. There are only a few things that have not been standardized, for example regarding the type, price, quantity, color, place, time, and several other things that are specific to the object of the agreement. In other words, what is standardized is not the form of the agreement, but the clauses [21].

As Hondius said, the contents of the agreement were not discussed with the other party, while the other party was only asked to accept or reject the unilaterally making standard agreement by the manager more motivated by economic gain, while PPPSRS was on the side of the disadvantaged, both regarding rights and obligations, clauses agreement and profit sharing.

Jessel M.R. in the case of "Printing and Numerical Registering Co. vs. Samson" argues that the principle of freedom of contract is intended ...men of full age understanding shall have the utmost liberty of contracting, and that contracts which are freely and voluntarily entered into shall be held and onforce by court you are not lightly to interfere with this freedom of contract. Then by borrowing Lawrence M. Friedmann's sub-system of law theory, which describes law as a system, and to be able to understand it, it is necessary to use a systems approach. Various understandings of law as a system, among others, put forward by Lawrence M. Friedman, that the law consists of components of structure, substance and culture [22].

The structural component is intended as an institution created by the legal system with various functions in order to support the operation of the system. This component is possible to see how the legal system provides services for the cultivation of legal materials on a regular basis. Then the substantive component, namely as the output of the legal system, in the form of regulations, decisions used by both the regulating and regulated parties. As well as the cultural component, which consists of values, attitudes, perceptions, custom, ways of doing, ways of thinking, opinions that affect the workings of law by Lawrence M. Friedman referred to as legal culture [3].

Friedman's theory actually wants to show the importance of the legal substance in regulating comprehensively, especially in this case regarding condotel management agreements. Why is that? This is of course to create certainty in the application of the law in society. With the existence of legal arrangements, this is actually an effort to prevent deviations that have the potential to harm certain parties.

In fact, the absence of regulation regarding the making of a cooperation agreement between the manager and PPPSRS has had a bad impact as evidenced by several cases of disputes between the manager and the owner of the condotel. One of the studies conducted by the Directorate General of Consumer Empowerment and Order of Commerce of the Ministry of Trade, the National Consumer Protection Agency (BPKN), the Consumer Dispute Resolution Agency (BPSK Jakarta), Real Estate Indonesia (DPD REI Jakarta), the Indonesian Consumers Foundation (YLKI), Indonesia Property Watch (IPW) at least there are several things that often become problems that are often experienced by consumers of flats, including in this case including condotel [2].

- The discrepancy between what has been promised by the developer and the reality of the apartment received by the consumer

- Clear and transparent information is not obtained from the developer, especially regarding matters relating to the incompatibility of the conditions of the promised supporting facilities and infrastructure with the reality, the status of the land, the condition of the final physical results of the house and others.

- Consumers cannot choose freely the bank that provides housing loans (KPR) or apartment ownership loans (KPA).

- The system of selling flats (apartments) on a pre-sale basis or selling pictures that apparently have not yet obtained a development permit, while the consumer's installment money has gone to the developer.

- Certificates that are not immediately handed over by developers to consumers.

- Consumers are often tempted by low prices and continue to pay installments, but there is no binding agreement between the consumer and the developer in the form of a binding sale and purchase agreement (PPJB).

From these complaints, broadly speaking, the problems that occur in the field in the field of flats themselves can be grouped into three categories, namely: 
- During the buying and selling process in which problems arise at the time of binding the sale and purchase (signing PPJB). Neither the exact time as agreed nor the contents of the PPJB which are generally quite burdensome for consumers.

- When making installment payments where there are frequent cancellations of unilateral buying and selling by the developer and there is a clause that regulates installment payments that are burdensome or detrimental to consumers.

- When you become the owner, namely regarding the management of the occupants, the increase in electricity rates unilaterally without the occupants knowing, the quality of the building that is not in accordance with what was agreed at the beginning of the PPJB binding, the problem of public facilities and social facilities (General and social facilities) that are not in accordance with what was promised by the party developers, environmental issues and others.

The implementation of hotel condominium agreements so far has not had a juridical footing in Indonesia, this has resulted in many developers and builders who often seek big profits without heeding the principles of good ethics in buying and selling agreements and managing hotel condominiums. The weakness that makes the condominium hotel agreement policy in Indonesia not fair is the weakness of the legislation in the form of not regulating the contents of the hotel condominium agreement and the position of the hotel condominium in Law buying and managing hotel condominiums, and the habitual factor of hotel condominium development and construction actors who seek profit through sale and purchase agreements and hotel condominium management by excluding consumers or hotel condominium owners. So it is necessary to reconstruct Law Number 20 of 2011 concerning Flats [23]

\section{Conclusion}

- The implementation of hotel condominium agreements so far does not have a legal footing in Indonesia, this has resulted in many developers and builders who often seek big profits without heeding the principles of good ethics in buying and selling agreements and managing hotel condominiums.

- The weakness that makes the condominium hotel agreement policy in Indonesia not fair is the weakness of the laws and regulations in the form of not regulating the contents of the hotel condominium agreement and the position of the hotel condominium agreement in Law Number 20 of 2011, the weakness of law enforcement in the form of no supervision related to the sale and purchase agreement and management of hotel condominiums, and the habitual factor of hotel condominium development and construction actors who mostly seek profit through sale and purchase agreements and hotel condominium management by excluding consumers or hotel condominium owners. The reconstruction is related to the addition of the definition of condominium hotel clearly in Article 1 of Law Number 20 of 2011 concerning Flats, then adding emphasis on provisions related to the application of Articles 42 to Article 50 to the arrangement of hotel condominiums. Then add the matter of supervising the implementation of the hotel condominium agreement and add sanctions against violators of the hotel condominium agreement.

\section{Compliance with ethical standards}

\section{Acknowledgments}

The author is grateful to all those who have contributed and helped in completing this article.

\section{Disclosure of conflict of interest}

The authors declare that there is no conflict of interest that would affect the findings of this study.

\section{References}

[1] MA Junyu. “Hospitality Industry Contract Is an Agreement," J. Pembaharuan Huk. 2020; 7(1): 75-84.

[2] AA Tedja, E Agustin. "Liablity of The Parties of Condotel Management Contract," Yuridika. 2019; 34(2): 215.

[3] D Setyo, D Putra, A Munandar, S Hs. "Analysis of Cooperation Agreement on Hotel Development and Management (Study At Hotel Lian)," Int. J. Humanit. Relig. Soc. Sci. 2017, 2021; 3(1).

[4] SE Wahyuningsih, S Atmoko, M Iksan. "The implementation of punishment theories in the verdict of narcotics case by judge in Indonesia," Test Eng. Manag. 2020; 83, 2797, 2797-2806. 
[5] SE Wahyuningsih, MR Srikusuma, M Iksan. "The efforts to utilize village funds in order to prevent criminal actions of corruption in Indonesia," 2021; 7(4): 246-251.

[6] E Bader, A Lababedi. “Hotel Management Contracts in Europe,” J. Retail Leis. Pro. 2007; 6(2): 171-179.

[7] CT Kuo. “A novel condominium management mode in Taiwan,” J. Urban Manag. 2020; 9(1): 6-18.

[8] R Schlup. “Hotel management agreements: Balancing the interests of owners and operators," J. Retail Leis. Pro. 2004; 3(4): 331-342.

[9] A Fatah. “Regional Legal Assistance,” Rechtsidee. 2015; 2(1): 1-10.

[10] IK Seregig, T Suryanto, B Hartono, E Rivai, E Prasetyawati. "Preventing the acts of corruption through legal community education,” J. Soc. Stud. Educ. Res. 2018; 9(2): 138-159.

[11] Joel H Samuels. “Condominium Arrangements in International Practice: Reviving an Abandoned Concept of Boundary Dispute Resolution,” Michigan J. Int. Law. 2007; 29(4): 727.

[12] O Sharma. "India and the united nations convention on the law of the sea," Ocean Dev. Int. Law. 1995; 26(4): 391412.

[13] NA Morgan. “Marketing and business performance," J. Acad. Mark. Sci. 2012; 40(1): 102-119.

[14] BD Lewis, A Hendrawan. "The impact of majority coalitions on local government spending, service delivery, and corruption in Indonesia," Eur. J. Polit. Econ. May 2018; 58: 178-191. 2019.

[15] T Keszey, W Biemans. “Sales-marketing encroachment effects on innovation,” J. Bus. Res. 2016; 69(9): 36983706.

[16] A Ismayawati. “Pancasila sebagai Dasar Pembangunan Hukum Di Indonesia,” YUDISIA J. Pemikir. Huk. dan Huk. Islam. 2018; 8(1): 53.

[17] JJ Norris, H Grol-prokopczyk. "International Journal of Law , Crime and Justice Entrapment allegations in rightwing terrorism cases : A mixed- methods analysis,” Int. J. Law Crime Justice. August 2017; 53: 77-88, 2018.

[18] IA Maerani. "Implementasi Ide Keseimbangan Dalam Pembangunan Hukum Pidana Indonesia Berbasis Nilai-Nilai Pancasila," J. Pembaharuan Huk. 2015; 11(2): 329-338.

[19] D Guilfoyle. "Maritime Law Enforcement Operations and Intelligence in an Age of Maritime Security Maritime Law Enforcement Operations and Intelligence in an Age of Maritime Security,”. 2017; 93.

[20] K Maulidah, NS Jaya. "Kebijakan Formulasi Asas Permaafan Hakim Dalam Upaya Pembaharuan Hukum Pidana Nasional," J. Pembang. Huk. Indones. 2019; 1(3): 281-293.

[21] V Vial, J Hanoteau. “Corruption, manufacturing plant growth, and the Asian Paradox: Indonesian evidence,” World Dev. 2010; 38(5): 693-705.

[22] E Nahartyo H. "Magnitude of Corruption, Rationalization, and Internal Control Quality: an Experimental Study on Subsequent Offense," J. Akunt. dan Keuang. Indones. 2018; 15(2): 164-179.

[23] LC Leonidou, CN Leonidou, TA Fotiadis, A Zeriti. "Resources and capabilities as drivers of hotel environmental marketing strategy: Implications for competitive advantage and performance,” Tour. Manag. 2013; 35: 94-110. 